\title{
TIKAWE'S LAST SONG
}

\author{
MARGARET ORBELL
}

Thanks to the literary labours of Māori authorities and interested Pākehā, thousands of texts of traditional Māori songs were recorded in the 19th and early 20 th centuries.

Many were published in early books and articles, while others are preserved in manuscripts in our public libraries.

As editor, translator and commentator, Dr Margaret Orbell has been studying these songs for more than thirty years and has published much on the subject. In 1996 she gave a seminar at the Stout

Research Centre, her topic being songs and poetic imagery relating to Raukawa (Cook Strait).

Having retired as Associate Professor of Māori at the University of Canterbury, Orbell is now a full-time writer living in Auckland. One of her main interests has always been the very extensive body of traditional poetry produced by Māori women, and at present she is working in this area. The following article brings together from several published sources the information which is available about a well-known waiata by Tikawe, a woman of Ngāti Pikiao.

$\mathrm{M}$ OTUTAWA PENINSULA on the southwest shore of beautiful Lake Rotoiti was for many generations the site of Te Taiki Pā, one of the main strongholds of Ngāti Pikiao. On the peninsula's northeast point, a high white cliff that once formed part of the defences of the pā is known as Te Rerenga a Tikawe [Tikawe's leaping place]. Tikawe's story, and her songs, have been remembered.

Like all pā, Te Taiki was a ceremonial centre as well as a fortress, a place where people from the surrounding district joined the permanent occupants to entertain visitors, debate politics, participate in seasonal rituals, celebrate births, and mourn deaths. The names of some of the carved houses that stood there are still remembered, and those of their owners. And it is known that around 1820, when an army from Waikato threatened the region, people living in smaller pā at the western end of the lake sought shelter with their relatives there. Together they carried in extra supplies, strengthened the palisades, then waited - some 500 men, women and children - to see if the enemy would attack. The warriors did not come, and Ngāti Pikiao were soon able to return to their homes.

In the late 1830 s, many of the occupants of Te Taiki moved to the coast to cut flax in the Maketū swamps - for they were now involved in an arms race, toiling to produce flax fibre to exchange for muskets offered by Pākehā traders. Probably the events relating to Tikawe took place before this migration, although we can be sure only that they occurred before the great Arawa writer Te Rangikāheke wrote down the words of her song in about $1850 .{ }^{1}$

Tikawe was a woman of rank whose husband, Te Aitu, had, according to some accounts, abandoned her. Certainly at this time Te Aitu was living far away at Te Whanganui o 'Rotu, the harbour at Ahuriri. ${ }^{2}$ In his absence Tikawe became the subject of gossip, accused of taking lovers. In answer to these insults she composed a waiata whakautu [waiata of reply] denying the slander and asserting her mana. Dressed in her finest garments, she stood on the marae at Te Taiki and sang her song. Then she walked to the edge of the cliff and leapt to the lake below. 


\section{Kāore te kōrero}

Kāore te kōrero, te haohao nunui,

Ko wai ngā tāne i tata mai ki taku taha?

I hoki atu anō i te pou w[h]akairo [o] te roro!

Nāwai Mawera kia mate haramai.

Aku rongo hanihani ka puta i ngā w[h]enua,

Ka haruru ki taw[h]iti, ki te huka o te tai

Kei Te W[h]anganui o 'Rotu - Te Aitu!

Kia whakarikaia te matea, ${ }^{3} \overline{1}$, e rūnā nei ki te w[h]are,

Kia hei taku ate i te tau o tōna tiki,

Kia tia whakaripa i te kōtore huia,

Kia kahu pūrua i te neko pakipaki,

Ka pai au te hoki ki te koko i [W]hangaroa!

E kore te ure e tata mai rā, i te whakawehi.

I patua taku hika ki te tororire rā i te ngahengahe,

I tāhekea iho he au kawa kei taku tinana.
Alas, so much talk

Alas, so much talk, so much spite,

Who are these men who have been near me?

They turned back from the carved posts of the porch!

No wonder Mawera wanted so much to come.

Insulting stories have gone throughout the land,

Resounding as far as the sea foam

At Te Whanganui o 'Rotu, and Te Aitu.

Let the shame hidden in the house be cast off,

Let his tiki's string be hung about my liver

And huia plumes fastened at the sides of my head,

Let me be clothed in a pair of bordered cloaks

To look fine as I return to the bay at Whangaroa.

No penis will come near, they'll be too much in awe.

My sex was struck with the tororire of the forest,

A bitter stream was poured on my body.
In her song Tikawe first confronts the gossips, declaring that no men would have dared approach the carved tupuna in the porch of her house. Mawera must have expressed an interest in her, or been said to do so; we are told he belonged to Ngāti Kahungunu, in the region where Te Aitu was then living. ${ }^{4}$ The malicious gossip has gone all the way to Te Whanganui o 'Rotu, where Te Aitu will have heard it - and Te Aitu, Tikawe proudly asserts, will offer his support.

Poetically speaking, it is not just the gossip about Tikawe but the woman herself who has travelled to Te Whanganui o 'Rotu, and Te Aitu will now present her with family treasures to wear on her return journey. He will hang his tiki around her neck, and it will rest upon her liver (for the liver, with the heart, was regarded as the seat of the affections, and Tikawe - as she here declares - still loves her husband). Two rare huia plumes will be placed in her hair, and she will wear fine cloaks with wide tāniko borders. These precious taonga, indicating as they do the support of Te Aitu, will frighten away any men who might otherwise have misjudged the situation.

Developing this idea further, Tikawe brings her song to a strong conclusion by claiming to have made herself bitter to men by pouring upon her body the bitter juice of the tororire tree. ${ }^{5}$ This metaphor is traditional and formulaic, expressed in language repeated, always with variation, from one song to another. The poet may speak of tororire juice, or the juice of the ngaio tree or the koheriki. ${ }^{6}$

Whangaroa, the home to which Tikawe speaks of returning, is an inlet in Lake Rotoehu, close to Lake Rotoiti. ${ }^{7}$ She sang her song, however, at Te Taiki Pā, perhaps to be in the presence of the people who had verbally attacked her but certainly also because the high cliff close to the main marae at Te Taiki was 'a famous suicide cliff' of her iwi. ${ }^{8}$ Having made up her mind to die, Tikawe intended to do it the proper way, following the ritual procedure established by her tūpuna.

Suicide [whakamomori] was fairly common in traditional Māori society. Often it happened when a person had been shamed, even if they were not to blame; in this situation, removing oneself with tragic finality from one's large and very close kinship group was a way of restoring honour and redeeming a lost reputation. Partly it was a kind of revenge, since the death of a single person diminished the entire group. Women in particular, it seems, might jump to their death after singing an appropriate song well knowing that their song would be remembered, and their story with it. ${ }^{9}$

After Te Taiki Pā was abandoned it became an urupā (burial ground), and Tikawe lies there now with her relatives. Her song passed down in Ngāti Pikiao tradition and 
was sung in her memory. As well, it travelled even further than the gossip had done, to regions where her name was unknown and her circumstances were understood only from the words of the song.
Here too its eloquence was valued.

$\infty$

\section{NOTES}

\section{References}

Grey, George 1853. Ko nga moteatea, me nga hakirara o nga Maori. Stokes, Wellington.

Johansen, J. Prytz 1954. The Maori and his religion in its non-ritualistic aspects. Munksgaard, Copenhagen.

McGregor, John (1893). Popular Maori Songs. Field, Auckland.

Ngata, A. T. 1959. Nga Moteatea. Vol I Polynesian Society, Wellington.

Orbell, Margaret 1977. Themes and images in Maori love poetry. PhD thesis, University of Auckland.

Orbell, Margaret 1992. Traditional Maori stories. Reed, Auckland.

Pomare, Maui and James Cowan 1930-34. Legends of the Maori. 2 vols. Fine Arts, Wellington.

Stafford, D. M. 1996. Landmarks of Te Arawa. Volume 2: Rotoiti, Rotoehu, Rotoma. Reed, Auckland.

\section{Notes}

1 Te Rangikāheke's manuscript (GNZMMSS 81: 94) is in the George Grey Collection in the Auckland City Libraries. This is the version which is followed here; I am grateful for permission to publish it. Another version was published by Grey (1853: 204) and subsequently, with minor changes, by Ngata (1959: 50-51); this variant version is discussed in footnote 5 below. Ngata includes some valuable information provided by Raureti Mokonuiarangi. Pomare and Cowan (1930-34: I, 75-79) publish only an attempt at translation, but include explanations given to Cowan by an unnamed Mãori man who was an authority on the region. Further information about places, pā and history is in Stafford 1996. I am indebted to all these authorities.

2 The present English name for Ahuriri is Napier. The full name of the harbour is Te Whanganui o Orotu; much of it disappeared in the earthquake of 1931. The name of this harbour sometimes referred also to the region around it.

3 Also in McGregor 1893: 54, though Grey 1853: 204 and Ngata 1959: 50 have simply 'mate.' 'Matea' must be formed from 'mate.' Possibly it is a passive form employed in an unusual way.
4 Raureti Mokonuiarangi gives this explanation in Ngata 1959: 50-51.

5 While this image referring to an 'au kawa' [bitter stream] must certainly have been in the original text, a variant version of the last two lines appears in Grey 1853: 204, in McGregor 1893: 54, and (in a text based on Grey's one) in Ngata 1959: 5051:

I patua taku kiri ki te tororire rā i te ngahengahe, My skin was struck with the tororire of the forest,

Raukawa was poured upon my body. Here the word hika [female genitals] has been replaced by kiri [skin], and 'au kawa' [bitter stream] by raukawa (this being an aromatic plant with leaves from which a scent was made)

These modified lines thus become an extension of the earlier passage describing Tikawe's splendid appearance as she returns from Te Aitu. Tororire juice, according to Ngata (1959: 50-51), was used as a dye in tattooing. In this variant version the reference to tororire juice is reinterpreted as being a declaration by Tikawe that she has been tattooed, while in the last line she is understood as speaking of the raukawa scent she is wearing.

Ngata's acceptance of Grey's version (1853: 204) suggests that this variant version with 'raukawa' continued to be
I tāhekea iho he raukawa kei taku tinana. sung by some singers. It is clear, however, that the original version (with 'au kawa') translation published by Pomare and Cowan (1930-34: I, 79) ends with the words 'bitterness is in my soul, ah me'.

6 Examples of this image are discussed in Orbell 1977: I, 182-88. Sometimes the poet, instead of saying that she herself has chosen to make herself bitter, may complain that she has become 'bitter' (unattractive) to a former lover who now rejects her.

7 There is another Whangaroa in Lake Rotomā, but Raureti Mokonuiarangi explains that Tikawe's Whangaroa is an inlet in Rotoehu (Ngata 1959: 50-51). Information published by Stafford (1996:46-47) shows this part of Rotoehu to be in the territory of Ngāti Pikiao.

8 This is said in Pomare and Cowan 193034: I, 76.

9 There is a brief discussion of whakamomori in Johansen 1954: 57-61. For another occasion on which a woman who had been shamed leapt from a height after singing a song in the presence of the persons responsible, see Orbell 1992:155-58. In such circumstances people killed themselves only when shamed by the insults of relatives or spouses, never in response to the insults of unrelated persons. These were dealt with in other ways. was also sung, for the (very free)

\section{Celebrating the 1940 Centennial}

\section{$=$ CALL FOR PAPERS}

In November 1999 the Stout Research Centre

will be holding a two-day seminar on the national celebra-

tions (including the 1939-40 Wellington Exhibition) marking

New Zealand's first hundred years.

\author{
Abstracts of papers are invited, for 30-minute slots, \\ and should be sent to: \\ J.M. Thomson, Stout Research Centre, \\ Victoria University of Wellington, PO Box 600, Wellington
}

